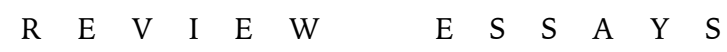

PIOTR T. KWIATKOWSKI

SWPS University, Warsaw

\title{
POLISH SOCIOLOGY IN THE FACE OF SOCIAL AND POLITICAL CHANGES OF THE 20TH CENTURY
}

Antoni Sułek specialises in social research methodology, and spent almost half a century teaching the subject to successive generations of sociology students at the University of Warsaw. He is a keen observer and commentator on the social and historical transformations taking place in Poland, was a consultant for the opinion research institute TNS Polska for many years, and from 1999 to 2001 was chief advisor on social affairs to Prime Minister Jerzy Buzek. He has also long been interested in the history of sociology, although while analysing the past of the social sciences he remains an expert on methodology and researcher of social phenomena. This explains why two questions reoccur in his works in the history of the social sciences: the first regarding the degree to which the social and political context impacts the development of sociology, and the secondon whether sociology and sociologists are capable of exerting an influence on the social and political reality surrounding them. In the introduction to his recently-published book A Mirror on the High Road, Sulek (2019: 11) writes: "Sociology in Poland was created by three forces: the changing historical conditions and problems experienced by Polish society; the varying historical circumstances and political contexts determining the prospects for the social sciences; and new intellectual currents and sociological concepts originating in other parts of the world". It is precisely these three 
forces that determine the research perspective long present in this author's works on the history of Polish sociology, most of which have been published in Polish (cf. Sułek 2001, 2002, 2011). Which is why it must be added at this point that an important strength of his latest book is that it has been published in English-thanks to which the findings of many years of work by an outstanding Polish sociologist have become accessible to the international circle of researchers interested in the history of the social sciences in Central Europe in the $20^{\text {th }}$ century.

The author has developed his own style of research and how he presents his findings. A genre in which he has achieved mastery is the small monograph, a comprehensive and erudite scientific treatise focusing on a specific and precisely defined issue. The book in question is therefore not a systematic presentation of the history of Polish sociology, but constitutes a collection of ten texts on selected issues, ones that Sułek acknowledged as particularly important and deserving a thorough rethink. Although each text may be read as a separate presentation on a particular topic, backed up by thorough studies, when taken as a set they comprise a whole, constituting a review of the key issues that Polish sociologists strived to tackle in the $20^{\text {th }}$ century.

The first chapter constitutes an accolade to sociological imagination. In the year 1893 a young Polish anthropologist and sociologist travels to the United States to visit the famous World's Columbian Exposition in Chicago. He begins his journey in Europe, the political borders of which have been set back in the second decade of the $19^{\text {th }}$ century. The continent is undergoing rapid change and development, with the majority of its population appreciating the progress made by civilisation, believing in science, and looking into the future with trust. The countries of Central Europe do not exist on the political maps of the day, and the economic and social changes are only just gathering pace in this backward part of the continent. The young representative of the first generation of Karl Marx's disciples sets off on his journey from a part of the Old Continent which is under the rule of three conservative monarchies: Russian, German, and Austro-Hungarian, empires that seem exceptionally stable and mighty. In the USA, Krzywicki becomes familiar with democratic, multicultural and dynamic society. His attention focuses on a few matters; he investigates the educational system, and is curious about issues related to agriculture-still the predominant area of the economy in Central and Eastern Europe towards the end of the $19^{\text {th }}$ century. But the most important in his American expedition is the direct confrontation with the new and as yet unknown society. The experience led the young sociologist to realise that studious 
observation and continuous contact with real life is the most important source of inspiration for and the factor stimulating the development of the social sciences. Upon his return from America, Krzywicki spent over four decades working as a scholar. He witnessed the Great War that convulsed Europe, and the comprehensive changes that followed in its wake. He never ceased to be interested in social theory, but remained receptive to real life itself; he focused a great deal of his attention on research, and in Poland-which recovered its independence in 1918-he initiated the establishing of new research institutions, for example the Central Statistical Office formed in 1918, and-at the Institute of Social Economy [Instytut Gospodarstwa Społecznego-IGS] - a section of the Association of Polish Economists and Statisticians established in 1920 for the purpose of conducting social, political and economic research studies. The year 1933 saw the publication in Leipzig of a work recounting the findings of pioneering research conducted in the factory settlement of Marienthal near Vienna, and showing the destructive impact of unemployment on the lives and personalities of people affected by lack of work, and on the state of the local collectivity (Jahoda, Lazarsfeld, Zeisel 1933/2007). At this time the Institute of Social Economy announced a competition for the memoirs of the unemployed, and collected and partially published abundant documentation of their lives, their problems, as well as their fears and breakdowns caused by deepening poverty and the lack of future prospects (Pamiętniki... 1933). This pioneering project was one of many research studies into unemployment conducted in the crisis-hit Poland of the 1930s. These projects, discussed by Sułek in a separate chapter, say a great deal about the development of Polish sociology in the period of 1918-39, and testify to the social sensitivity of the researchers of the day, as well as their creative inventiveness in regard to methodological exploration. Studies using biographical documents and ethnographic methods were developing at this time in Poland, as too were the first attempts at conducting surveys.

When addressing the selected themes concerning the development of Polish sociology post 1918, the author poses a question regarding its relations with the directions of theory and research in other countries. The diagnosis contained in the book in question is unequivocal: putting aside a few examples (such as the international career of Florian Znaniecki), Polish sociology was (and remains to this day) peripheral in character, having not created new and influential theoretic or methodological orientations with international reach, while creatively absorbing theories and methodological approaches developed abroad. An example is the reception for Émile Durkheim's work Le suicide. Étude de sociologie first published in 1897. 
This book reached Poland quickly, and met with a positive reception, although the first Polish reviewers did not notice the proposal for practising science contained within it; this suggested that empirical facts remain connected to verifiable theory, while theory enables the interpretation of facts and determines the direction of further exploration. During the interwar period, Polish sociologists considered Durkheim a classic, although (despite Stefan Czarnowski being one of this school's representatives) they rarely cited his works, and Le suicide remained the least well known of them. It was only after World War II that Polish sociology, undergoing dynamic development after the year 1956, returned to Durkheim's concept. This occurred largely thanks to the work of American sociologists who turned back to this work, seeing in it an important theoretical inspiration for empirical research.

The relations between Polish and American sociology are the subject of a separate treatise contained in this volume. The years 1939-56 was exceptionally hard for Polish sociology. Many scholars died during the War, while the social sciences, recovering in the years 1945-1948, were thrown out of the country's academic institutions during the years of Stalinism. It was only post 1956 that Polish sociology was born again. Although some researchers returned to works and concepts from before the War, the most important changes occurred as a result of opening up to the outside world. The social sciences in Poland became more involved in developing collaboration with scholars in Western Europe and in particular from the United States) than in other Eastern Bloc countries. The nature of this collaboration varied; it embraced visits by foreign sociologists to Poland, the participation of Polish researchers in international conferences, joint projects, and foreign fellowships for Polish sociologists in leading American centres of research. The growth of international contacts and travel to the USA changed Polish sociology. New theories and models of empirical sociology spread throughout Poland, new directions of research emerged, and specialised sub-disciplines of sociology also began developing.

For approximately half of the book ( 6 chapters) the author focuses on issues in Polish sociology from the mid 1950s to the turn of the 1990s. ${ }^{1}$ In this section, Sułek tackles a number of important matters. The first is the achievements of the reborn sociology, in which context the research conducted by Stanisław Ossowski's students, discussed in a separate chapter, deserve particular attention. In 1957 a team of sociologists from the Uni-

${ }^{1}$ A systematic review of the growth of sociology after World War II see: Marta Bucholc, Sociology in Poland. To Be Continued? (2016). 
versity of Warsaw, headed by Stefan Nowak, commenced preparations for a large-scale survey among students attending higher places of learning in Warsaw. They selected a random sample of students and over the next eight months carefully prepared a questionnaire containing 75 questions. Their 'Students of Warsaw' polls focused on opinions regarding socialism, Marxism, and the political developments of the recent past. Values important to the students, as well as attitudes towards patriotism and other nations, were also investigated. This research was conducted in 1958, and in 1961 the opinion polls were repeated on a random sample of students attending Warsaw's largest higher place of learning, the University of Technology (Nowak 1991). The survey findings met with significant public interest both in Poland and abroad. For example Paul F. Lazarsfeld rated the research very highly, seeing in it a synthesis of the Polish tradition of logic and modern methodological techniques. But the history of surveys embracing Warsaw students did not end here. For many years to come, students of sociology at the University of Warsaw used them to learn survey methods. Many of the questions from the questionnaire were used in various surveys conducted in later years. Ultimately, under Stefan Nowak's supervision, the polls were repeated in the years 1978, 1983, 1985-86 and in 1988. Thus a sociological record was established of attitudes and opinions held by the young Polish intelligentsia from the fall of Stalinism to the fall of communism. Sułek also recalls other projects: Stefan Nowak's study on psychological aspects of the social structure conducted in 1961, and projects carried out by other students of Ossowski, Andrzej Malewski and Irena Nowakowska. One could extend the list of interesting and important projects from the late nineteen-fifties and early nineteen-sixties, and recall the formation of the first institution in Eastern Bloc countries regularly surveying opinions and attitudes: Public Opinion Research Centre [OBOP—Ośrodek Badania Opinii Publicznej] (Pawełczyńska 1960), or the work of sociologists in Łódź-the first electoral surveys (Gostkowski 1959). Two very apt remarks by the author refer to all these activities, and concern the communist authorities' critical attitude towards the development of Polish sociology. The potential of Polish sociology was only partly tapped, since much of the researchers' energy was wasted on disputes with censors and on overcoming bureaucratic hurdles. Interesting ideas were ruined by prohibitions, while public discussion of the surveys was rendered impossible through the banning of the publication of their results. A separate topic tackled by Antoni Sulek is that of the usage of social opinion poll results as sources for social history research. Although I fully agree in this respect with the author's views, 
somehow historians are not being persuaded to read old and yellowing sociological reports, while sociologists are more interested in contemporary problems than the attitudes and opinions of people who entered their adulthood approximately 60 years ago.

A second matter is the failure of Polish sociology in the second half of the $20^{\text {th }}$ century. Antoni Sułek, a demanding academic teacher, gives a harsh appraisal of Polish sociologists, formulating the categorical thesis that Polish sociology did not anticipate the events of Solidarity, just as it was incapable of forecasting the occurrences of 1989. Such a hypothesis is taken by the author as the starting point for reflection over the condition of sociological theory of the 1970s, which had not come up with a theory of the society of real socialism taking its structural contradictions and dynamics into account. Another reason for the absence of forecasts was the domination of surveys, which diagnose correctly the status quo and focus on the centre of the social system. Such surveys disappoint when one has to explore communities and groups in which new ideas and trends emerge. In Sułek's opinion, the lack of a correct forecast of the growth of the social movement is a lesson in humility for representatives of the social sciences (and, I would add, not only sociology), but also constitutes experience showing that one cannot anticipate novel developments, meaning unique social phenomena that have not yet existed and will only be created in the future. And the Solidarity of the years $1980-81$ was just such a large-scale social novelty, in addition one of many shapes and undergoing rapid change. While acknowledging that the author was right in many points, I believe that he is too harsh in his overall appraisal. It is indeed true that nobody published one coherent text containing a forecast. Yet many publications and conference or congress speeches included the recurrent view of growing social discontent, accurate economic forecasts were given, and the inability of the political system to resolve problems, or the exhaustion of its symbolic resources, was indicated. Therefore, even if Solidarity was unexpected, it did not appear entirely out of the blue. Representatives of the social sciences had known much earlier that a storm was brewing.

The third matter is the change of methodological paradigm in Polish sociology. Here the chapter bears the dramatic title: "The Rise and Decline of Survey Sociology in Poland". At this point there is a certain anecdote worth recalling. According to a widely-repeated legend, one major American newspaper actually printed Mark Twain's obituary and, when the writer was told about this by a reporter, he answered: "The reports of my death are greatly exaggerated." Reports regarding the "decline of surveys" also seem exaggerated, although the author does provide serious 
arguments to back up his thesis. Firstly, Polish sociology from 1956 onwards was largely dominated by surveys, treated as the peak achievement of the social sciences. The events of the years 1980-81, but also of the year 1989, were serious lessons revealing the limitations of this method. Simultaneously, new theoretical concepts and new research approaches were gaining in importance in many academic centres. It would seem that more opinion polls were conducted in the difficult years of the 1980s in Poland than in previous decades. However, increasingly common surveys conducted using qualitative methods and the results of survey research were compared with data from other sources. As the author emphasises, opinion polls do have a few enduring strengths, such as enabling the comparison of changes in attitudes and opinions over time, and international analyses. This is why since 1990 surveys have been conducted regularly, why researchers' attention is drawn by large and regularly conducted international projects, and why reports from public opinion polls are published in the media almost every day. One cannot therefore speak of the death of survey research, although it has undoubtedly been dethroned, is no longer the 'king' of empirical sociology, and has become one of many methods used in academic sociology and in numerous applied social research studies. And in research practice today, the accepted standard is the procedure of triangulation-involving analysis of a defined phenomenon using data obtained from various sources and using different methods of research.

The fourth matter is the historical analysis of surveys conducted in the 1980s. The author analyses the functioning of one institution: the governmental Public Opinion Research Centre (CBOS). This centre was established as a governmental agency following the crisis of the years 1980-81. By creating their own such centre, the authorities gained a source of data on opinions and attitudes. This data could serve to optimise political decisions, but also propaganda. The authorities' usage of survey findings for political fighting in the nineteen-eighties had diverse consequences: on the one hand, it contributed to an increase in social awareness of surveys, while on the other it provoked doubts regarding the honesty and the credibility of their findings. The chapters on this period may be read from two points of view today. They constitute interesting contributions to the social history of the last years of the Polish People's Republic. But they also maintain important topical significance. Detailed analyses testify to how deeply sociological surveys are set in the social context. How the respondents perceive the political scene determines whether they want to share their true thoughts and views with the pollsters. But the possibility of expressing one's own opinion in such surveys depends not only on the scope 
of freedom present in the country concerned. Authentic public opinion requires the existence of language used to talk about public issues, language that is familiar to the members of the collectivity in question.

In the closing chapter, Antoni Sułek presents his vision of socially-involved sociology. The strength of sociology lies, in his opinion, in its methodology, with which specific phenomena can be correctly defined, impartially analysed, and systematically investigated. And this in turn enables evidence-based debate and policy. As Sułek (2019: 190) writes: "Discussion in the scientific community could be a model for public debate, and scientists who appear in the agora could propagate such a model and push the debate in the direction of rational discussion". The social sciences could contribute important concepts, ideas and meanings enabling the interpretation of social phenomena to such a civilised, substantive discussion. As the author summarises: "In general: (1) sociology in Poland should be more, and not less socially engaged, but more on behalf of society than on behalf of the world of power; (2) the social activeness of sociology should develop in various directions, particularly in the direction of its humanist function, and not only of social technology; (3) the postulate of social engagement does not interfere with sociology's calling as a science" (Sułek 2019: 201). Scientific method, discussion based on data, impartial analysis, and factual discussion... A clear and coherent programme. Rarely, though, does one encounter such a vision of public debate in the era of liquid modernity, virtual reality, post-politics and post-truth.

Transl. Jonathan Weber

\section{REFERENCES}

Bucholc, Marta. 2016. Sociology in Poland. To Be Continued? London: Palgrave Macmillan.

Gostkowski, Zygmunt. 1959. "Popular interest in the municipal elections in Lodz, Poland." Public Opinion Quarterly 23: 371-381.

Jahoda, Marie, Paul F. Lazarsfeld, Hans Zeisel. 1933. Die Arbaitlosen von Marienthal. Ein soziographischer Versuch über die Wirkungen langandauernder Arbeitslosigkeit. Leipzig: Hirzel; Polish edition: Bezrobotni Marienthalu [transl. Robert Marszałek; scienific edition and final commentary by Antoni Sulek]. Oficyna Naukowa, Warszawa 2007.

Nowak, Stefan. 1991. „Zamiast wstępu” \& „Studenci Warszawy 1958-1978 - uwagi o problematyce i metodzie". In: Stefan Nowak (ed.). Studenci Warszawy. Studium dtugofalowych przemian postaw $i$ wartości. Warszawa: Wydawnictwa Uniwersytetu Warszawskiego.

Pamiętniki. 1933. Pamiętniki bezrobotnych. 1-57 [foreword by Ludwik Krzywicki], Warszawa: Instytut Gospodarstwa Społecznego.

Pawełczyńska, Anna. 1960. „Z pracy Ośrodka Badania Opinii Publicznej przy Polskim Radio i TV." Kultura i Spoteczeństwo 4: 188-201. 
Sułek, Antoni. 2001. Sondaż polski. Przygarść rozpraw o badaniach ankietowych. Warszawa: IFiS PAN.

Sułek, Antoni. 2002. Ogród metodologii socjologicznej. Warszawa: Scholar.

Sułek, Antoni. 2011. Obrazy z życia socjologii w Polsce. Warszawa: Oficyna Naukowa.

Sułek, Antoni. 2019. A Mirror on the High Road. Chapters from the History of Social Research in Poland. Berlin: Peter Lang.

\begin{abstract}
The author of this essay deals with the specificity of sociology in Poland, reaching for the book of Antoni Sułek A Mirror on the High Road. Chapters from the History of Social Research in Poland (2019). Chapters of this book taken as a set constitute a review of the key issues that Polish sociologists strived to tackle in the 20th century. For approximately half of the book (6 chapters) Sułek focuses on issues of Polish sociology from the mid-1950s to the turn of the 1990s: the first is the change of theoretical and methodological paradigms in Polish sociology in the second half of the $20^{\text {th }}$ century; the second is the successes of Polish sociology, but also its weaknesses - the author devoted much space to the theoretical limitations that prevented sociologists from predicting the formation of Solidarity in 1980. The third topic is the historical analysis of surveys conducted in the last decade of communism - their reliability as well as social and political functions. Finally, Sułek's vision of socially-involved sociology appears. The strength of such sociology lies in its methodology, with which specific phenomena can be correctly defined, impartially analysed, and systematically investigated. And this in turn enables evidence-based debate and policy.
\end{abstract}

Key words: history of Polish sociology, methodology of social research, sociological theory, socially involved sociology, relations between Polish and American sociology, social transformation in Poland

Stowa kluczowe: historia socjologii w Polsce, metodologia badań społecznych, teoria socjologiczna, socjologia zaangażowana, relacje między polską i amerykańską socjologią, transformacja społeczna w Polsce 